\title{
SELECTION OF THE COMPUTATIONAL MODEL OF WIND FLOW IN THE PROBLEMS OF COMPUTATIONAL ARCHITECTURAL AND CIVIL ENGINEERING AERODYNAMICS IN ACCORDANSE WITH REGULATORY AND TECHNICAL DOCUMENTS
}

\author{
Andrei V. Deineko, Aleksey I. Shamshurin, Narek A. Kazaryan \\ Spectrum Group of Companies, Moscow, RUSSIA
}

\begin{abstract}
An overview of the main directions of numerical simulation of problems of architectural and civil engineering aerodynamics based on Computational Fluid Dynamics (CFD) is presented. The main advantages of numerical simulation in comparison with traditional methods of aero-physical modeling in wind tunnels are highlighted. The basic principles of numerical simulation of wind loads and actions on buildings and structures are outlined. In modern practice, numerical modeling by finite volume method is used with the decomposition of the velocity of the turbulent wind flow into the average and pulsation component within the averaged by Reynolds solution of Navier-Stokes equations using the semi-empirical turbulence model k- $\omega$ SST. In practice, the problem of the legitimate (in accordance with the requirements of building codes) selection of a computational model of wind flow is very important. This is equivalent to the assignment of boundary conditions within numerical simulation. The computational model of the wind, presented in the Russian building codes, requires additions to solve the problems of numerical simulation of architectural and civil engineering aerodynamics. A detailed comparison of the computational models of wind flow in Russian and foreign building codes is carried out. The following wind flow parameters are analyzed: the profile of the average wind speed, the profile of the intensity of turbulence, the profile of the scale of turbulence. A table of correspondence of terrain types according to the classification of Russian and foreign codes is proposed. The possibility of determining the parameters of the computational wind flow model based on the joint use of building codes in force in Russia and Belarus is shown. A set of measures is proposed with the goal of creating a regulatory and technical environment for the practical application of computational architectural and civil engineering aerodynamics in real design.
\end{abstract}

Keywords: numerical simulation, computational architectural and civil engineering aerodynamics, computational fluid dynamics (CFD), wind loads, pedestrian comfort

\section{ВЫБОР РАСЧЁТНОЙ МОДЕЛИ ВЕТРОВОГО ПОТОКА В ЗАДАЧАХ ВЫЧИСЛИТЕЛЬНОЙ АРХИТЕКТУРНО- СТРОИТЕЛЬНОЙ АЭРОДИНАМИКИ В СВЕТЕ НОРМАТИВНО-ТЕХНИЧЕСКОЙ БАЗЫ}

\author{
А.В. Дейнеко, А.И. Шамшурин, Н.А. Казарян
}

Группа компаний «Спектрум», г. Москва, РОССИЯ

\begin{abstract}
Аннотация: Представлен обзор основных направлений численного моделирования задач архитектурностроительной аэродинамики на основе вычислительной механики жидкости и газа (CFD-технологий). Отмечены основные преимущества численного моделирования по сравнению с традиционными способами аэрофизического моделирования в аэродинамических трубах. Изложены базовые принципы численного моделирования ветровых нагрузок и воздействий на здания и сооружения. В современной практике применяется численное моделирование методом конечных объёмов с разложением скорости турбулентного ветрового потока на среднюю и пульсационную составляющую в рамках решения осреднённых по Рейнольдсу уравнений Навье-Стокса с использованием полуэмпирической модели турбулентности $\mathrm{k}-$ $\omega \mathrm{SST}$. На практике большое значение имеет проблема легитимного (в соответствии с требованиями строительных норм) выбора расчётной модели ветрового потока, что эквивалентно назначению гранич-
\end{abstract}


Selection of the Computational Model of Wind Flow in the Problems of Computational Architectural and Civil Engineering Aerodynamics in Accordance with Regulatory and Technical Documents

ных условий в рамках численного моделирования. Расчётная модель ветра, представленная в российских строительных нормах, требует дополнения для решения задач численного моделирования архитектурностроительной аэродинамики. Проведено детальное сопоставление расчётных моделей ветрового потока в российских и зарубежных строительных нормах. Проанализированы следующие параметры ветрового потока: профиль средней скорости ветра, профиль интенсивности турбулентности, профиль масштаба турбулентности. Предложена таблица соответствия типов местности по классификации российских и зарубежных норм. Показана возможность определения параметров расчётной модели ветрового потока на основе совместного использования строительных норм, действующих в России и Белоруссии. Предложен комплекс мер с целью создания нормативно-технический условий для практического применения вычислительной архитектурно-строительной аэродинамики в реальном проектировании.

\author{
Ключевые слова: численное моделирование, \\ вычислительная архитектурно-строительная аэродинамика, \\ вычислительная механика жидкости и газа (CFD-технологии), ветровые нагрузки, \\ пешеходная комфортность
}

\section{INTRODUCTION IN COMPUTATIONAL ARCHITECTURAL- CONSTRUCTIONAL AERODYNAMIC}

A major achievement of the theory and practice of design justification for buildings and structures in the 21 st century becomes the development of a new direction of calculation - numerical modeling of architectural-constructional aerodynamics using computational fluid dynamics, CFD technology. The following areas of practical application of computational architectural-construction aerodynamics, as well as the environmental and wind energy aerodynamics that are close to one in the methodological sense, were formed [1-7]:

- external aerodynamics (environmental aerodynamics), i.e. modeling of wind flows in the surface boundary layer, taking into account the influence of the surrounding buildings and terrain:

o determination of wind loads and impacts on buildings and structures;

o determination of snow loads on buildings and structures;

$\circ$ evaluation of wind pedestrian comfort and justification of wind-protective measures;

$\circ$ modeling the spread of air pollution, evaluating the effectiveness of sanitary protection zones (SPZ), modeling accident scenarios;
○ assessment of environmental comfort and justification of measures for environmental protection;

○ modeling of the wind energy potential of the area, optimization of the arrangement of wind generators within wind power plants;

- internal aerodynamics, i.e. simulation of air movement in the premises, taking into account the operation of the heating system, ventilation and air conditioning (HVAC):

o room microclimate modeling to optimize the HVAC system in order to achieve optimal (and not only acceptable) microclimate parameters in $100 \%$ of the working area, as well as to increase energy efficiency due to rationalization of air distribution;

- modeling of the distribution and disposal of industrial air pollution and scenic smoke;

o modeling of smoke removal and gas fire extinguishing.

Let us note the "flagship" role of numerical modeling of wind loads, the methodology of which summarizes the main scientific and practical issues of architectural-constructional aerodynamics, and the requirements for wind loads, methodological and reference data are regulated by regulatory and technical documents [8-12]. Let us reveal the advantages and new possibilities of numerical modeling of wind loads in 
comparison with traditional methods of aerophysical research in wind tunnels:

- practical one, related to the expansion of the possibilities of computational justification:

o consideration without any decrease in the accuracy of arbitrary area of the territory, arbitrary configuration of the building, arbitrary surrounding building, any terrain;

o detailing the distribution of wind load during $100 \%$ of the facade area;

o the ability to analyze the results at any point in the problem area of the numerical model, including the one that is not originally planned;

- calculational-theoretical advantages related to the refinement of the modeling statement:

○ modeling in natural scale of space and speed, that solves the problem of similarity;

o transfer to the setting of the external flow (from the setting of the internal flow), that reduces the influence of the borders of the simulation region;

o the absence of flow distortions from measuring instruments, which allows to obtain any necessary discretization of the results.

\section{CFD-TECHNOLOGIES IN XXI CENTURY}

The formation of continuous flow mechanics in the meaning, that is close to the modern, began in the XVIII century, that is associated with the names of academicians of the Russian Academy of Sciences Leonard Eyler and Daniel Bernoulli. In the 19th century, Navier, Poisson, SaintVenant and Stokes formulated a general law of flow motion in the form of a system of differential partial differential equations (Navier-Stokes equations), which are the basis of modern numerical simulation.

The development of computational mechanics of liquids and gases (CFD-technologies) [13-
14] dates back to the 1980s, when the first industrial software systems were developed, the new versions of which are used to this day: PHOENICS (Great Britain 1981); FIDAP (USA, 1982), Fluent (USA, 1983), TASCflow (Canada, 1985), Flow3D / CFX (United Kingdom, 1980s), the last four soft wares have been merged into ANSYS CFD now; Flow-3D (USA, 1985); Star CD (UK / USA, 1989); FlowVision (USSR / Russia, 1991).

Currently, CFD-technologies are widely implemented in practical engineering work in many industries, with deep integration into the design and design processes.

The technologies of high-performance computing are being improved, in particular, parallel computing on the graphic processors of the CUDA technology [15].

Multi-physical (interdisciplinary, connected) calculations are being actively implemented, based on the modeling of various physical aspects of the design scheme (such as stress-strain state, heat transfer, aerohydrodynamics) in interaction. In particular, this allows calculations of buildings and structures in an aeroelastic arrangement.

\section{AN APPROACH TO NUMERICAL MODELING OF WIND FLOWS}

Numerical modeling of aerodynamic problems is performed, as a rule, by the finite volume method (FVM). For this, a grid approximation of the calculated area of the airspace is carried out, and boundary and initial conditions are assigned. Analogously to the strength finiteelement calculations, the construction of an effective finite-volume grid requires rational discretization of the characteristic regions of the aerodynamic design scheme taking into account the factor of grid convergence.

It is convenient to accept a cylindrical form of the calculated area of the airspace, in order that the conditions of numerical simulation are similar for any wind direction. The lower surface of the model reproduces the investigated building, 
Selection of the Computational Model of Wind Flow in the Problems of Computational Architectural and Civil Engineering Aerodynamics in Accordance with Regulatory and Technical Documents

the surrounding building and the terrain. The height of the model equals to approximately 10 characteristic height of the highest object in the design scheme, but not less than the height of the prism boundary layer

$0.5 \mathrm{~km}$, within which the boundary conditions vary significantly throughout the height. The model's radius is assigned taking into account the specific features of the investigated building, surrounding constructions and terrain, and reaches $1-2 \mathrm{~km}$.

Due to frictional forces, viscous air near the surface (ground or wind front of the building) is braked, as a result of which the air velocity at the surface tends to zero. In the wall laminar sublayer air velocity is small. As the distance from the surface increases, the speed increases according to the logarithmic law until the speed of the main flow is reached.

The thickness of the near-wall layer and the nature of the distribution of velocity in it depend on the roughness of the surface. It is formed, for example, by niches of window openings in the facade of a building or by trees on the surface of the earth. There are two approaches to the modeling of roughness: explicit or using near-wall functions. For the wind front of the building, the first method is suitable, which assumes accurate reproduction of the geometry of the wind front of the building (parapets, window openings, etc.). For large areas of the earth's surface, the second method is suitable, when the roughness (formed by vegetation and the construction of settlements) is assigned as a parameter of the wall function based on reference data. Approximate parameters of roughness for various types of terrain are given, for example, in foreign standards, discussed below.

Wind flows are assumed to be incompressible (since the wind speed is substantially lower than the speed of sound) and isothermal [1-5].

The simulation of turbulent air movement is based on the decomposition of velocity into the average and pulsating component. Reynoldsaveraged Navier-Stokes equations (ReynoldsAveraged Navier-Stokes, RANS) proposed by Reynolds in 1895 are solved. In this case, turbu- lent stresses, or Reynolds stresses, are introduced that takes into account the losses and redistribution of energy in the turbulent flow (as compared to the laminar flow), which are random in nature. For its definition, semi-empirical models of turbulence are used.

For solving a wide range of practical engineering problems when modeling incompressible flows, the model of the type k- $\varepsilon$ is used most often. For near-wall flows, models of the $k-\omega$ type are widely used, in particular, the shear stress transfer model $k-\omega$ SST (Shear Stress Transport) [16].

Since the interaction of flow with surfaces plays a large role in wind aerodynamic problems, it is advisable to use $k-\omega \mathrm{SST}$ as the main model of turbulence.

According to the Euler method, the results of aerodynamic calculations are presented as flow parameters at a particular point in the nonmoving space at certain points in time, i.e. the fields of flow parameters and the change of fields in time are considered. The trajectories of the movement of elementary volumes of air can be restrictedly represented as current lines.

The main engineering results of numerical simulation are:

- distribution of the main and peak wind load on the wind front of the building;

- spectrum of the main wind load;

- total aerodynamic force on the building and torque relative to the selected point;

- distribution of wind speeds at the height of pedestrians, assumed to be $1.5 \mathrm{~m}$ from the ground [12].

The wind load is understood to be the wind pressure (active pressure or wind suction, the sum of the average and pulsation component) determined in design conditions according to building codes.

The main wind load is the wind load at a specific wind direction.

Peak wind load is the largest wind loado that is possible on the considered fragment of the wind front.

The main wind load is taken into account in constructive calculations of the bearing system 
of the building as a set of loads of different size and direction, acting simultaneously on the entire area of the wind front (on the windward, leeward and lateral sides, on the envelop). Accordingly, the main wind load is determined for those wind directions for which constructive calculations of the bearing system are necessary (usually at four directions along the main axes). Peak wind load is taken into account in constructive calculations of facade, large window, advertising and other structures, located at the wind front of the building and working locally, regardless of the load on the other parts of the wind front. Peak wind load corresponds to the lower and upper envelope ( $\min / \max$ imposition) of wind pressures obtained from calculations for various wind directions. Accordingly, it is necessary to take into account the representative number of directions of the wind. In practice, from 16 to 32 directions are taken into account, usually 24 directions (an angular step of $\left.15^{\circ}\right)$ [1, 3].

The results of numerical simulation can be compared with the results of aero-physical tests in a wind tunnel:

- main and peak wind load, as well as the wind load spectrum - with the results of drainage tests, when the wind pressure is measured on the scale model at the points of drainage (holes connected to a pressure gauge);

- total aerodynamic force and torque - with the results of weight tests, when the force and torque are measured on a scale model using aerodynamic weights;

- wind speeds in the pedestrian zone - with the results of airflow visualization using the method of mulberry or a digital tracer visualization method.

\section{SELECTION OF THE DESIGN MODEL OF A WIND FLOW}

The legitimate choice of the design model of the wind flow, which corresponds to the purpose of the boundary conditions at numerical simula- tion, is one of the key issues that has been addressed by experts in the field of computer and experimental aerodynamics.

Let us emphasize that in wind aerodynamics, the design scheme of the airspace corresponds to the conditions of strong wind. The purpose of the calculations is to determine the wind load on the buildings, to study the interaction of the building and the wind flow in the aero elastic formulation, and also to estimate the wind pedestrian comfort. Consequently, the wind flow model should cover the range of average speeds starting from the level of wind discomfort of about $6 \mathrm{~m} / \mathrm{s}$ and up to $45 \mathrm{~m} / \mathrm{s}$ (which corresponds to the VII wind region according to Table 1 below). Other speed modes do not require regulation in documents on wind loads on buildings and structures.

The ability of the wind to exert wind pressure is due to the kinetic energy of the moving air and is characterized by the velocity head $W$ :

$$
W=\rho V^{2} / 2
$$

where $V$ is velocity of air moving; $\rho$ is air density.

The atmosphere is turbulent. The velocity of the air (and hence the velocity head) undergoes random fluctuations or pulsations, which are subject to statistical laws. In accordance with the above RANS-approach, the velocity is described by the average component of the velocity $V_{m}$, equal to its expectation, and the standard deviation $\sigma_{\mathrm{V}}$. The degree of turbulence is conveniently characterized by the intensity of turbulence I, expressed in relative units or percentages:

$$
I=\sigma_{V} / V_{m}
$$

In a gust, the wind speed deviates from $V_{m}$ more than $\sigma_{V}$. Deviations of more than the pulsation velocity component $V_{p}=\gamma_{V} \sigma_{V}$ rarely occur, where $\gamma_{V}$ is usually called the coefficient of security, which usually takes values from 3 to 4 . Similarly, the velocity head $W_{m}$, its standard deviation $\sigma_{W}$, the velocity pulsation component 
can be considered head $W_{p}$ and coefficient of security $\gamma_{W}$.

It is fundamentally important to take into account the duration of the wind as the implementation of a random process, which determines the probability of deviation of the wind flow parameters from the expected values during the considered period of time.

Changes in wind speed occur in a wide range [17-20], and the spectrum is divided into two parts, as shown in figure 1 [17]. The left part is macro meteorological, in which changes in wind force are associated with changes in weather and have periods from several hours to a month. The right side is micrometeorological, where changes in speed are associated with turbulence and have periods from 3 seconds to 10 minutes.

From this it follows that it is rational to conduct statistical processing of wind measurements on two time scales - macro meteorological and micrometeorological, which is customary in world wind engineering.

For definiteness, let us denote the speed and wind pressure, given by specific recurrence, in lower case letters $v$ and $w$.

The average wind speed $v_{m}$ is usually understood as a speed averaged over a 10-minute period, exceeding on average 1 time in 5 years (the annual probability of exceeding 0.2 or 1 case for 262,980 10-minute observation cycles), or 1 time in 50 years (annual probability of exceeding 0.02 or 1 case per 2,629,800 observation cycles).

The pulsation component of the wind speed $v_{p}$ means the maximum value of the speed averaged over a time interval significantly less than 10 minutes. As a rule, a 3-second period is considered. Accordingly, the standard deviation $\sigma_{-} \mathrm{v}$ characterizes the distribution of the velocity deviation with a 3 -second averaging of the corresponding speed with a 10 -minute averaging under strong wind conditions. The probability of exceeding $v_{p}$ in the regulatory documents is not specified. Moreover, the characteristic period for estimating the probability of exceeding $v_{p}$ is 10 minutes, i.e. 200 cycles of 3 seconds.
Thus, the computational model is a wind flow with an average speed $v_{m}$ with gusts up to the speed $v_{m}+v_{p}$. To describe the wind flow with engineering accuracy must be considered:

- average speed and its change in height $v_{m}(z)$

- turbulence intensity and its change in height $I(z)$;

- the periodicity of the velocity pulsation, which can be represented by the scale of turbulence and its variation in the height $L(z)$.

The scale of turbulence is the length of the largest eddies. In the atmosphere, large eddies break up into smaller ones (turbulent cascade), which is taken into account in numerical simulation using the turbulence model. The passage of different-scale vortices carrying different kinetic energy forms the spectrum of wind impact.

The Russian regulatory documents [8-12] are based on regionalization by wind pressure; wind speed is not considered. The standard wind pressure $w_{0}$ is the velocity head of the wind flow in an open area at a height of $10 \mathrm{~m}$, averaged over a 10-minute period, exceeding on average 1 time in 5 years.

The wind load is considered as the sum of the average $\mathrm{w}_{m}$ and the pulsation $\mathrm{w}_{p}$ component with a wind load coefficient $\gamma_{f}$ of 1.4:

$$
\gamma_{f} w\left(z_{e}\right)=\gamma_{f}\left(\mathrm{w}_{m}\left(z_{e}\right)+\mathrm{w}_{p}\left(z_{e}\right)\right)
$$

The wind load reliability coefficient $\gamma_{f}$ plays the role of a probabilistic transition coefficient from 5 -year to 50-year repeatability [20].

The change in wind pressure in height and the influence of the type of terrain are taken into account separately for the average and pulsating component:

$$
\begin{gathered}
\gamma_{f} \mathrm{w}_{m}\left(z_{e}\right)=\gamma_{f} \mathrm{w}_{0} k\left(z_{e}\right) c \\
\gamma_{f} \mathrm{w}_{p}\left(z_{e}\right)=\gamma_{f} \mathrm{w}_{m} \xi \zeta\left(z_{e}\right) v
\end{gathered}
$$

where $k\left(z_{e}\right)$ is coefficient depending on the type of terrain, taking into account the change in 
the average component for the equivalent height $z_{e}$; $\zeta\left(z_{e}\right)$ is wind pressure ripple factor, depending on the type of terrain, taking into account the change in the pulsation component for the equivalent height $z_{e}$;

$\mathrm{c}$ is aerodynamic pressure coefficient depending on the shape of the wind front;

$v$ is the coefficient of spatial correlation of the wind pressure fluctuations, depending on the size and aspect ratio of the building surface under consideration;

$\xi$ is the dynamic factor, depending on the height and first frequency of the building's natural oscillations, not taken into account for the majority of buildings of ordinary height.

Let us clarify, that to describe the wind flow in the framework of numerical modeling, instead of wind pressure, we consider a velocity head equivalent to wind pressure without taking into account coefficients depending on the building, i.e. with unit values of the coefficients $\mathrm{c}, v, \xi$, as well as with an equivalent height $z_{e}$ equal to the ordinary height $\mathrm{z}$. The wind load is formed taking into account the geometry of the building and the mode of wind flow around it as a result of aerodynamic calculation.

The relationship between velocity head and wind speed, taking into account the frequency of occurrence, is determined by the formulas [8-10]:

$$
\begin{aligned}
& \mathrm{w}_{0}=0,43 v_{50}^{2} \\
& \mathrm{w}_{0}=0,61 v_{0}^{2}
\end{aligned}
$$

where $v_{0}$ and $v_{50}$ are, respectively, wind speed exceeded on average once every 5 and 50 years. Let us note that the coefficient of 0.61 is equal to $\rho /$ at an air density of $1.22 \mathrm{~kg} / \mathrm{m}^{3}$, which corresponds to the conditions of the international standard atmosphere.

The coefficient 0.43 has a similar physical meaning and additionally includes a probabilistic coefficient of transition from 5-year to 50year repeatability.

Therefore, we have:

$$
\begin{gathered}
v_{50} / v_{0}=1.19 \\
w_{50} / w_{0}=1.42 \approx \gamma_{f}=1.4
\end{gathered}
$$

The estimated average wind speed, determined taking into account the coefficient $\gamma_{f}$, has a 50year repeatability:

$$
v_{m}(z)=\left(\gamma_{f} w_{0} k(z) / 0.61\right)^{0.5}
$$

The maximum wind speed in the gust is determined in the formula

$$
v_{\max }(z)=\left(\gamma_{f} w_{0} k(z)(1+\zeta(z)) / 0.61\right)^{0.5}
$$

Russian norms [8-12] do not provide information on the definition of the standard of speed $\sigma_{v}(z)$, standard of velocity head $\sigma_{w}(z)$, intensity of turbulence $I(z)$, scale of turbulence $L(z)$.

To estimate these values, additional data are needed that are not included in the materials [812]. Consider 2 variants for determining $I(z)$.

Variant 1. According to data [19-20], the coefficient of provision of the pulsation component of the wind load is 3.0, i.e.

$$
\sigma_{w}(z)=\mathrm{w}_{\mathrm{p}}\left(z_{e}\right) / 3,
$$

whence we have:

$$
I(z)=(1+\zeta(z) / 3)^{0.5}-1
$$

Variant 2. According to the data of [2], the coefficient of security of the pulsation component of the wind speed is 3.5 , i.e.

$$
\sigma_{v}(z)=\mathrm{v}_{\mathrm{p}}\left(z_{e}\right) / 3.5,
$$

whence we have:

$$
I(z)=\left((1+\zeta(z))^{0.5}-1\right) / 3.5
$$

Thus, the assessment of the intensity of turbulence $I(z)$ is contradictory and requires additional data that are not fixed in the normative literature. 
It is not possible to estimate the profile of the scale of turbulence $L(z)$ using normative data.

In general, the determination of turbulence parameters, in our opinion, is beyond the limits of the applicability of the method [8-10], therefore, formulas (12) and (13) cannot be used for practical calculations.

Thus, the computational model of wind flow, which forms the basis of Russian norms, is not enough for numerical simulation. This necessitates the recourse to foreign norms. The most detailed design model of wind flow, according to our assessment, is presented by Eurocode [21] and in the Italian CNR-DT standards [22]. These documents allow to explicitly define the desired parameters $v_{m}(z), I(z), L(z)$. Let us note that the Russian translation of the Eurocode [21] was officially introduced in Belarus as a technical code of established practice [23].

Foreign standards [21-23] use zoning by wind speed, which is taken as the speed in an open area at a height of $10 \mathrm{~m}$, averaged over a 10minute period, exceeded on average once every 50 years. This speed is equivalent to $v_{50}$ according to the notation adopted above, or $v_{m}$ at a height of $10 \mathrm{~m}$, determined taking into account the coefficient $\gamma_{f}$.

Let us consider the parameters of the calculated wind flow model according to [21, 23]:

$$
\begin{gathered}
v_{m}(z)=c_{r}(z) c_{o}(z) v_{b} c_{p r o b} \\
c_{r}(z)=k_{r} \ln \left(z / z_{0}\right) \\
k_{r}=0.19\left(z_{0} / 0.05\right)^{0.07} \\
v_{b}=c_{\text {dir }} c_{\text {season }} v_{b, 0} \\
\left.\begin{array}{c}
(z)=\sigma_{v} / v_{m}(z) \\
\sigma_{v}=k_{r} v_{b} k_{I}
\end{array}\right\} \\
\left.\begin{array}{c}
\alpha(z)=L_{t}\left(z / z_{t}\right)^{\alpha} \\
\alpha=0.67+0.05 \ln \left(z_{0}\right)
\end{array}\right\} \\
z_{\min } \leq z \leq z_{\max }
\end{gathered}
$$

where $v_{b, 0}$ is the main value of the base wind speed according to wind zoning (normal value); $v_{b}$ is the basic value of wind speed;

$c_{\text {dir }}$ is wind direction coefficient of 1.0 unless otherwise indicated in the Eurocode national application; $c_{\text {season }}$ is a seasonal coefficient of 1.0 , if there are not another indication in the national Euro code application; $k_{r}$ is area coefficient; $c_{r}(z)$ is coefficient taking into account the type of terrain; $c_{o}(z)$ is orographic coefficient equal to 1.0 for an average slope less than $3^{\circ}$ (approximately $5 \%) ; c_{\text {prob }}$ is probabilistic coefficient of 1.0 with 50 -year repeatability; $\sigma_{v}$ is pulsation standard deviation of wind speed; $k_{I}$ is turbulence coefficient of 1.0 unless otherwise indicated in the Eurocode national application; $L_{t}$ is base turbulence scale; $z_{t}$ is turbulence base height; $z_{0}$ is roughness parameter according to type of terrain according to Eurocode (table 2); $z_{\min }$ is the minimum height according to the Eurocode locality (Table 2), if $z<z_{\min }$ it should be accepted $z=z_{\min } ; z_{\max }=200 \mathrm{~m}$ is a maximum height for applying formulas.

For comparison, we consider the parameters of the calculated wind flow model according to [22].

$$
\left.\begin{array}{c}
v_{m}(z)=v_{r} c_{m}(z) \\
c_{m}(z)=k_{r} \ln \left(z / z_{0}\right) c_{t}(z) \\
v_{r}=v_{b} c_{r}
\end{array}\right\}
$$

where $v_{b}$ is the base value of wind speed according to wind zoning (standard value); $v_{r}$ is design value of wind speed; $c_{r}$ is probability coefficient equal to 1.0 with 50 -year repeatability; $c_{m}(z)$ is wind velocity profile coefficient; $k_{r}$ is area coefficient; $c_{t}$ is a topographical coefficient of 1.0 with an average slope less than $5 \% ; \bar{L}=300 \mathrm{M}$ is base turbulence scale; $\bar{Z}$ is turbulence base height; $\kappa$ - coefficient accepted by table from CNR-DT 207/2008 (Table 2); $z_{0}$ is roughness parameter according to type of terrain according to CNR-DT 207/2008 (Table 2); $z_{\min }$ is the minimum height according to CNR-DT 207/2008 (table 2), if $z<z_{\min }$ it should be accepted $z=z_{\min } ; z_{\max }=200 \mathrm{M}$ is a maximum height for applying formulas. 
A comparison of the calculated wind models is shown in Figures 2-4 using the example of the I wind region according to Russian standards. Accordingly, the base wind speed is assumed to be $23.0 \mathrm{~m} / \mathrm{s}$ according to Table 1 .

In all variants of the calculated model of wind, wind flow parameters are constant up to a certain $z_{\min }$ takes the value from 2 to $12 \mathrm{~m}$, depending on the type of terrain. It is in the section $z<z_{\min }$ that the difference in wind models is most noticeable. At $z>z_{\text {min }}$, the profiles of the calculated parameters of the wind flow in all models converge.

The averaged velocity profile $v_{m}(z)$ increases with height (Figure 2). For $z<z_{\min }$, Russian norms give the highest estimate of speed.

The turbulence intensity profile $I(z)$ decreases with height (Figure 3). The estimation of the intensity of turbulence using formulas (12) and (13) should be considered as unrepresentative. For $z<z_{\min }$, the Eurocode gives the greatest estimate of the intensity of turbulence.

The turbulence scale profile $L(z)$ increases with height (Figure 4). The greatest estimate of the scale of turbulence give Italian standards.

Since the physical characteristics of wind flows in the framework of wind aerodynamics are uniform for the entire prism boundary layer of the Earth, it seems appropriate to use data on the intensity and scale of turbulence borrowed from foreign norms in calculations for the territory of Russia. Namely, on the basis of the Technical Code of Established Practice [23], published in Russian and introduced in the Union State of Belarus. At the same time, the standard wind pressure $w_{0}$ should be taken according to wind zoning in accordance with current Russian standards [8-9]. It is advisable to take the profile of average wind speed according to Russian standards as the most conservative.

\section{NUMERICAL MODELING OF WIND LOADS AND NORMATIVE BASE}

In general, against the background of the progress of CFD-technologies and it widespread use for solving practical engineering problems in many industries, the method of numerical modeling of wind loads and impacts $[1,3]$ should be considered as formed part of the system of global engineering knowledge. The necessary initial data are fixed in the normativetechnical literature of a number of countries [21-22], including Belarus [23]. In Russia and abroad, great experience has been gained in practical calculations of wind loads in real design problems.

The urgency of the tasks of architecturalconstructional aerodynamics in modern construction is growing:

- the complicity of buildings' architectural formation increases, that makes it impossible to determine wind loads and impacts analytically according to the engineering methodology of the Rules;

- the use of light facade systems, for which it is important to correctly take into account the actual distribution of peak wind pressure over the facade area, is expanding;

- construction of buildings closes to each other (for example, towers on a common stylobate), and construction in conditions of dense urban development, where the influence of air flow interference on wind loads cannot be neglected, grows;

- high-rise construction is expanding, in particular, Russia owns records for the height of buildings in Europe (the "Federation Tower" with a height of $374 \mathrm{~m}$ in the Moscow International Business Center; the Lakhta Center under construction with a height of $462 \mathrm{~m}$ in St. Petersburg);

- increasing social and regulatory requirements for comfort, in particular, the assessment of wind pedestrian comfort is provided in $[8,9$ and 12].

At the same time, the degree of implementation of computational architectural-construction aerodynamics in real design significantly lags behind existing capabilities and international experience. The main reason for this state of affairs is the lack of a regulatory base, that does not allow us to present the results of numerical 
modeling of wind loads as part of the mandatory expertise of the project documentation.

In the Russian system of regulatory documentation, numerical modeling of wind loads and impacts is considered only in GOST R 56728-2015 "Buildings and structures. Method for determining wind loads on enclosing structures" [13]. However, this standard is focused on conducting experimental design studies and provides for numerical simulation exclusively in the formulation of a virtual wind tunnel, when the numerical model reproduces the conditions of an aero physical experiment in a wind tunnel, taking into account the scale of the simulation. Such a statement devaluates the computational and theoretical advantages of numerical simulation, which lies precisely in the simulation on a natural scale under external flow conditions.

In our opinion, the following solutions are necessary for the further development of computational architectural-constructional aerodynamics in Russia.

1. Adopt the Handbook to SP 20.13330.2016 "Loads and Impacts" for calculating wind loads and impacts using the methods of numerical architecture and roof aerodynamics based on the detailed proposals declared in [3]. The manual should contain specific requirements for aerodynamic design schemes and methods of numerical simulation.

In particular, the Manual should contain an algorithm for the purpose of the calculated model of the wind. We believe it is advisable to recommend the use of the algorithm considered in this article, based on the sharing of normativetechnical documents in force in Russia and Belarus.

2. To verify the software implementing CFD technology in relation to the determination of wind loads of impacts (similar to the verification of software for strength calculations, which has been carried out at RAACS for a number of years).

3. To supplement GOST R 56728-2015 with the section "Computer (numerical) modeling in the conditions of natural and man-made environment", in which to take into account the specif- ics of the development of numerical aerodynamic models of cylindrical configuration on a natural scale in the formulation of external flow.

In our opinion, among the common problems, the greatest advantages of numerical simulation of wind loads manifests itself in determining the peak wind load on buildings of ordinary height with light facade and stained glass systems.

\section{CONCLUSIONS}

1. The ability to numerically simulate the tasks of architectural-constructional aerodynamics using computational fluid and gas mechanics (CFD technologies) is due to the fundamental theoretical basis and many years of interdisciplinary experience in solving applied engineering problems in a wide range of parameters of the studied currents.

2. The necessary data for the purpose of the design model of the wind flow should be contained in the aggregate of regulatory and technical documents adopted in Russia and Belarus. The standards are available in Russian and, in our opinion, it should be recommended for joint use.

3. The development of the regulatory and technical base for wind loads and impacts, in our opinion, should go along the path of adopting the Handbook for SP 20.13330.2016 "Loads and Impacts" for calculating wind loads and impacts using computational architecturalconstructional aerodynamics.

\section{ACKNOWLEDGMENTS}

The authors are grateful for the organizational support of the work and the promotion of the implementation of computational architecturalconstructional aerodynamics in the real design of V.F. Ivanov, N.A. Clementyev and S.N. Suvorov (Spectrum Group); for useful discussions and valuable advice in preparing the work of N.N. Fedorova and S.A. Valger (Scientific and Educational Center of Computer Modeling 
"CADFEM-Sibstrin" at NSACEU); for a series of lectures at MGSU in 2018 within the framework of the author's advanced training program "Strategies for calculating wind influences. System views "M.I. Kazakevich.

Special thanks for the many years of mentoring in the field of computational architecturalconstructional aerodynamics, the authors express to S.I. Dubinsky.

\section{REFERENCES}

1. Dubinskii S.I. Chislennoe Modelirovanie Vetrovyh Vozdejstvij na Vysotnye Zdaniya [Numerical Modeling of Wind Effects on High-Rise Buildings]. Dis. kand. tekhn. nauk (Ph.D Thesis). Moscow, MGSU, 2010 (in Russian).

2. Poddaeva O.I., Kubenin A.S., Churin P.S. Arhitekturno-Stroitel'naya Aehrodinamika [Architectural and Building Aerodynamics]. Moscow, MGSU, 2015 (in Russian).

3. Belostotsky A.M., Akimov P.A., Afanaseva I.N. Vychislitel'naya Aehrodinamika $\mathrm{V}$ Zadachah Stroitel'stva [Computational Aerodynamics in Construction Problems]. Moscow, ASV Publishing House, 2017 (in Russian).

4. Valger S.A., Fedorova N.N., Fedorov A.V. Chislennoe Issledovanie Interfe-rencionnyh Effektov, Voznikajushhih v Vozdushnom Potoke pri Obtekanii Kom-pleksa Zdanij Slozhnoj Formy [Numerical Study of the Interference Effects Arising in the Air Flow in the Flow Around a Complex of Buildings of Complex Shape]. // Thermophysics and Aeromechanics, 2017, Volume 24, Number 1(103), pp. 35-44 (in Russian).

5. Valger S.A., Fedorova N.N., Fedorov A.V. Numerical Study of Atmospheric Air Flow in the Vicinity of Urban Environment. // AIP Conference Proceedings, 2016, 1770, Paper No 040017.

6. Valger S.A., Fedorova N.N., Fedorov A.V. Struktura Turbulentnogo Otryvnogo Techenija v Okrestnosti Ustanovlennoj na Plastine
Prizmy s Kvadratnym Secheniem [Structure of Turbulent Separated Flow in the Neighborhood of a Plate-Mounted Prism of Square Section]. // Thermophysics and Aeromechanics, 2015, Vol. 22, No. 1, pp. 29-42 (in Russian).

7. Khitrykh D.P. Opyt Modelirovaniya Processov Snegoperenosa i

Snegootlozheniya [Experience in the Simulation of Snow Transfer and Snow Deposition]. // ANSYS Advantage. Russian Edition, 2013, No. 19, pp. 27-32 (in Russian).

8. SP 20.13330.2016 Nagruzki i Vozdejstvija [Loads and Actions]. Actualized SNiP 2.01.07-85* (in Russian).

9. SP 20.13330.2011. Nagruzki i Vozdejstvija [Loads and Actions]. Actualized SNiP 2.01.07-85* (in Russian).

10. SNiP 2.01.07-85*. Nagruzki i Vozdejstvija [Loads and actions] (in Russian).

11. GOST R 56728-2015. Zdanija i Sooruzhenija. Metodika Opredelenija Vetrovyh Nagruzok na Ograzhdajushhie Konstrukcii [Buildings and Constructions. Method for Determining Wind Loads on the Building Envelope] (in Russian).

12. MDS 20-1.2006. Vremennye Rekomendacii po Naznacheniyu Nagruzok i Vozdejstvij, Dejstvuyushchih na Mogofunkcional'nye Vysotnye Zdaniya i Kompleksy v Moskve [Temporary Recommendations on the Designation of Loads and Impacts Acting on Multifunctional High-Rise Buildings and Complexes in Moscow] (in Russian).

13. Lyczkowski R.W. The History of Multiphase Science and Computational Fluid Dynamics. A Personal Memoir. Springer, 2018.

14. Weinhold I., Parry J. The Third Wave of CFD. NAFEMS World Congress, Salzburg, Austria, 2013.

15. Bocharov A.N., Balakirev B.A., Bityurin V.A. et al. Numerical Simulation as an Important Tool in Developing Novel Hypersonic Technologies. // Journal of Physics: Conference Series, 2015, Vol. 653. 
Selection of the Computational Model of Wind Flow in the Problems of Computational Architectural and Civil Engineering Aerodynamics in Accordance with Regulatory and Technical Documents

16. Menter F.R., Kuntz M., Langtry R. Ten Years of Industrial Experience with the SST Turbulence Model. // Proceedings of the 4th International Symposium on Turbulence, Heat and Mass Transfer, Begell House Inc., West Redding, 2003, pp. 625-632.

17. Van der Hoven I. Power Spectrum of Horizontal Wind Speed in the Frequency Range from 0.0007 to 900 Cycles per Hour. // J. Meteor., 1957, Volume 14, pp. 160-164.

18. Davenport A.G. The Spectrum of Horizontal Gustiness Near the Ground in High Winds. // J. Royal Meteorol. Soc., 1961, Volume 87, Issue 372, pp. 194-211.

19. Popov N.A. Rekomendacii po Utochnennomu Dinamicheskomu Raschetu Zdanij i Sooruzhenij na Dejstvie Pul'sacionnoj Sostavlyayushchej Vetrovoj nagruzki [Recommendations on the Updated Dynamic Calculation of Buildings and Structures for the Effect of the Pulsation Component of the Wind Load]. Moscow, CNIISK / EVROSOFT, 2000 (in Russian).

20. Cejtlin A.I., Bernshtejn A.S., Guseva N.I., Popov N.A. Novaya Redakciya Razdela "Vetrovye nagruzki" glavy SNiP "Nagruzki i vozdejstviya" [New Edition of the Section "Wind Loads" of the Head of SNiP "Loads and Impacts"]. // Stroitel'naya Mekhanika i Raschet Sooruzhenij, 1987, No. 6 (in Russian).

21. Eurocode 1: Actions on Structures - Part 14: General Actions - Wind actions. EN 1991-1-4:2005.

22. National Research Council of Italy. Advisory Committee on Technical Recommendations for Construction. Guide for the Assessment of Wind Actions and Effects on Structures. CNR-DT 207/2008.

23. Tekhnicheskij Kodeks Ustanovivshejsya Praktiki. TKP EN 1991-1-4-2009. Belorusskaya Redakciya. Evrokod 1. Vozdejstviya na Konstrukcii. Chast' 1-4. Obshchie Vozdejstviya. Vetrovye Vozdejstviya.

\section{СПИСОК ЛИТЕРАТУРЫ}

1. Дубинский С.И. Численное моделирование ветровых воздействий на высотные здания. Диссертация на соискание ученой степени кандидата технических наук. М.: МГСУ, 2010.

2. Поддаева О.И., Кубенин А.С., Чурин П.С. Архитектурно-строительная аэродинамика. - М.: МГСУ, 2015.

3. Белостоцкий А.М., Акимов П.А., Афанасьева И.Н. Вычислительная аэродинамика в задачах строительства. - М.: Издательство АСВ, 2017.

4. Вальгер С.А., Федорова Н.Н., Федоров А.В. Численное исследование интерференционных эффектов, возникающих в воздушном потоке при обтекании комплекса зданий сложной формы. // Теплофизика и аэромеханика, 2017, том 24, №1 (103), c. 35-44.

5. Valger S.A., Fedorova N.N., Fedorov A.V. Numerical Study of Atmospheric Air Flow in the Vicinity of Urban Environment. // AIP Conference Proceedings, 2016, Vol. 1770, Paper No 040017.

6. Вальгер С.А., Федорова Н.Н., Федоров A.В. Структура турбулентного отрывного течения в окрестности установленной на пластине призмы с квадратным сечением. // Теплофизика и аэромеханика, 2015, том 22, №1, c. 29-42.

7. Хитрых Д.П. Опыт моделирования процессов снегопереноса и снегоотложения. // ANSYS Advantage. Русская редакция, 2013, №19, c. 27-32.

8. СП 20.13330.2016 Нагрузки и воздействия. Актуализированная редакция СНиП 2.01.07-85*.

9. СП 20.13330.2011. Нагрузки и воздействия. Актуализированная редакция СНиП 2.01.07-85*.

10. СНиП 2.01.07-85*. Нагрузки и воздействия.

11. ГОСТ Р 56728-2015. Здания и сооружения. Методика определения ветровых нагрузок на ограждающие конструкции. 
12. МДС 20-1.2006. Временные рекомендации по назначению нагрузок и воздействий, действующих на многофункциональные высотные здания и комплексы в Москве.

13. Lyczkowski R.W. The History of Multiphase Science and Computational Fluid Dynamics. A Personal Memoir. Springer, 2018.

14. Weinhold I., Parry J. The Third Wave of CFD. NAFEMS World Congress, Salzburg, Austria, 2013.

15. Bocharov A.N., Balakirev B.A., Bityurin V.A. et al. Numerical Simulation as an Important Tool in Developing Novel Hypersonic Technologies. // Journal of Physics: Conference Series, 2015, Vol. 653.

16. Menter F.R., Kuntz M., Langtry R. Ten Years of Industrial Experience with the SST Turbulence Model. // Proceedings of the 4th International Symposium on Turbulence, Heat and Mass Transfer, Begell House Inc., West Redding, 2003, pp. 625-632.

17. Van der Hoven I. Power Spectrum of Horizontal Wind Speed in the Frequency Range from 0.0007 to 900 Cycles per Hour. // J. Meteor., 1957, Volume 14, pp. 160-164.

18. Davenport A.G. The Spectrum of Horizontal Gustiness Near the Ground in High Winds. // J. Royal Meteorol. Soc., 1961, Volume 87, Issue 372, pp. 194-211.

19. Попов Н.А. Рекомендации по уточненному динамическому расчету зданий и сооружений на действие пульсационной составляющей ветровой нагрузки. - М.: ЦНИИСК/ЕВРОСОФТ, 2000.

20. Цейтлин А.И., Бернштейн А.С., Гусева Н.И., Попов Н.А. Новая редакция раздела «Ветровые нагрузки» главы СНиП «Нагрузки и воздействия». // Cтроительная механика и расчет сооружений, 1987, №6.

21. Eurocode 1: Actions on Structures - Part 14: General Actions - Wind actions. EN 1991-1-4:2005.

22. National Research Council of Italy. Advisory Committee on Technical Recommendations for Construction. Guide for the As- sessment of Wind Actions and Effects on Structures. CNR-DT 207/2008.

23. Технический кодекс установившейся практики. ТКП ЕN 1991-1-4-2009. Белорусская редакция. Еврокод 1. Воздействия на конструкции. Часть 1-4. Общие воздействия. Ветровые воздействия.

Andrei V. Deineko, Ph.D., assistant professor, head of the center for computer simulation of Spectrum Group of Companies (Spectrum R\&D); Building 15, Complex 29, Academica Tupoleva Embankment, Moscow, 105005, Russia; phone: +7 (495) 981-68-88;

E-mail: deineko@spgr.ru;

https://www.spectrum-group.ru.

Aleksey I. Shamshurin, leading engineer of the center for computer simulation of Spectrum Group of Companies (Spectrum R\&D); Building 15, Complex 29, Academica Tupoleva Embankment, Moscow, 105005, Russia; phone: +7 (495) 981-68-88; e-mail: shamshurin@spgr.ru; https://www.spectrum-group.ru.

Narek A. Kazaryan, leading engineer of the center for computer simulation of Spectrum Group of Companies (Spectrum R\&D); Building 15, Complex 29, Academica Tupoleva Embankment, Moscow, 105005, Russia; phone: +7 (495) 981-68-88; e-mail: nkazaryan@spgr.ru; https://www.spectrum-group.ru.

Дейнеко Андрей Викторович, кандидат технических наук, доцент, руководитель центра компьютерного моделирования ГК «Спектрум» (Spectrum R\&D); 105005, Россия, Москва, Наб. Академика Туполева, 15, корп. 29; тел.: +7 (495) 981-68-88;

E-mail: deineko@spgr.ru;

https://www.spectrum-group.ru.

Шамшурин Алексей Игоревич, ведущий инженер центра компьютерного моделирования ГК «Спектрум» (Spectrum R\&D); 105005, Россия, Москва, Наб. Академика Туполева, 15, корп. 29; тел.: +7 (495) 981-68-88; e-mail: shamshurin@spgr.ru; https://www.spectrum-group.ru

Казарян Нарек Арменович, ведущий инженер центра компьютерного моделирования ГК «Спектрум» (Spectrum R\&D); 105005, Россия, Москва, Наб. Академика Туполева, 15, корп. 29; тел.: +7 (495) 981-68-88; E-mail: nkazaryan@spgr.ru; https://www.spectrum-group.ru 
Selection of the Computational Model of Wind Flow in the Problems of Computational Architectural and Civil Engineering Aerodynamics in Accordance with Regulatory and Technical Documents

Table 1. Wind zoning of the territory of Russia.

\begin{tabular}{|l|c|c|c|c|c|c|c|c|}
\hline Wind region & Ia & I & II & III & IV & V & VI & VII \\
\hline $\begin{array}{l}\text { Regulatory wind pressure } \\
\mathrm{w}_{0}, \mathrm{~Pa}\end{array}$ & 170 & 230 & 300 & 380 & 480 & 600 & 730 & 850 \\
\hline $\begin{array}{l}\text { Regulatory average wind } \\
\text { speed } \mathrm{v}_{0}, \mathrm{~m} / \mathrm{s}\end{array}$ & 16.7 & 19.4 & 22.2 & 25.0 & 28.1 & 31.4 & 34.6 & 37.3 \\
\hline $\begin{array}{l}\text { Estimated average wind speed } \\
\mathrm{V}_{\mathrm{m}} \approx \mathrm{V}_{50}, \mathrm{~m} / \mathrm{s}\end{array}$ & 19.8 & 23.0 & 26.2 & 29.5 & 33.2 & 37.1 & 40.9 & 44.2 \\
\hline
\end{tabular}

Table 2. Approximate compliance of types of terrain according to Russian and foreign norms.

\begin{tabular}{|c|c|c|c|c|c|c|c|}
\hline \multirow{3}{*}{\begin{tabular}{l}
\multicolumn{1}{c}{ Design codes } \\
Russian design codes \\
SP 20.13330.2011 [9], \\
SP 20.13330.2016 [8]
\end{tabular}} & Parametrs & \multicolumn{6}{|c|}{ Type of terrain } \\
\hline & Type of terrain & - & - & $\mathbf{A}$ & - & B & $\mathbf{C}$ \\
\hline & Minimum height $\mathrm{z}_{\min }$, meters & - & - & 5 & - & 5 & 10 \\
\hline \multirow{3}{*}{$\begin{array}{l}\text { Eurocode } \\
\text { EN 1991-1-4:2005 [21]; } \\
\text { Belarusian design codes } \\
\text { TKP EN 1991-1-4-2009 } \\
\text { [23] }\end{array}$} & $\begin{array}{l}\text { Type of terrain } \\
\text { (terrain category) }\end{array}$ & $\mathbf{0}$ & $\mathbf{I}$ & II & - & III & IV \\
\hline & $\begin{array}{l}\text { Roughness parameter } \mathrm{z}_{0}, \\
\text { meters }\end{array}$ & 0.003 & 0.01 & 0.05 & - & 0.3 & 1.0 \\
\hline & Minimum height $\mathrm{Z}_{\mathrm{min}}$, meters & 1 & 1 & 2 & - & 5 & 10 \\
\hline \multirow[t]{5}{*}{$\begin{array}{l}\text { Italian design codes } \\
\text { CNR-DT 207/2008 [22] }\end{array}$} & $\begin{array}{l}\text { Type of terrain } \\
\text { (exposure category) }\end{array}$ & - & $\mathbf{I}$ & II & III & IV & $\mathbf{V}$ \\
\hline & $\begin{array}{l}\text { Roughness parameter } \mathrm{z}_{0}, \\
\text { meters }\end{array}$ & - & 0.01 & 0.05 & 0.1 & 0.3 & 0.7 \\
\hline & Minimum height $\mathrm{z}_{\min }$, meters & - & 2 & 4 & 5 & 8 & 12 \\
\hline & Area coefficient $\mathrm{k}_{\mathrm{r}}$ & - & 0.17 & 0.19 & 0.20 & 0.22 & 0.23 \\
\hline & Table coefficient $\kappa$ & - & 0.44 & 0.52 & 0.55 & 0.61 & 0.65 \\
\hline
\end{tabular}

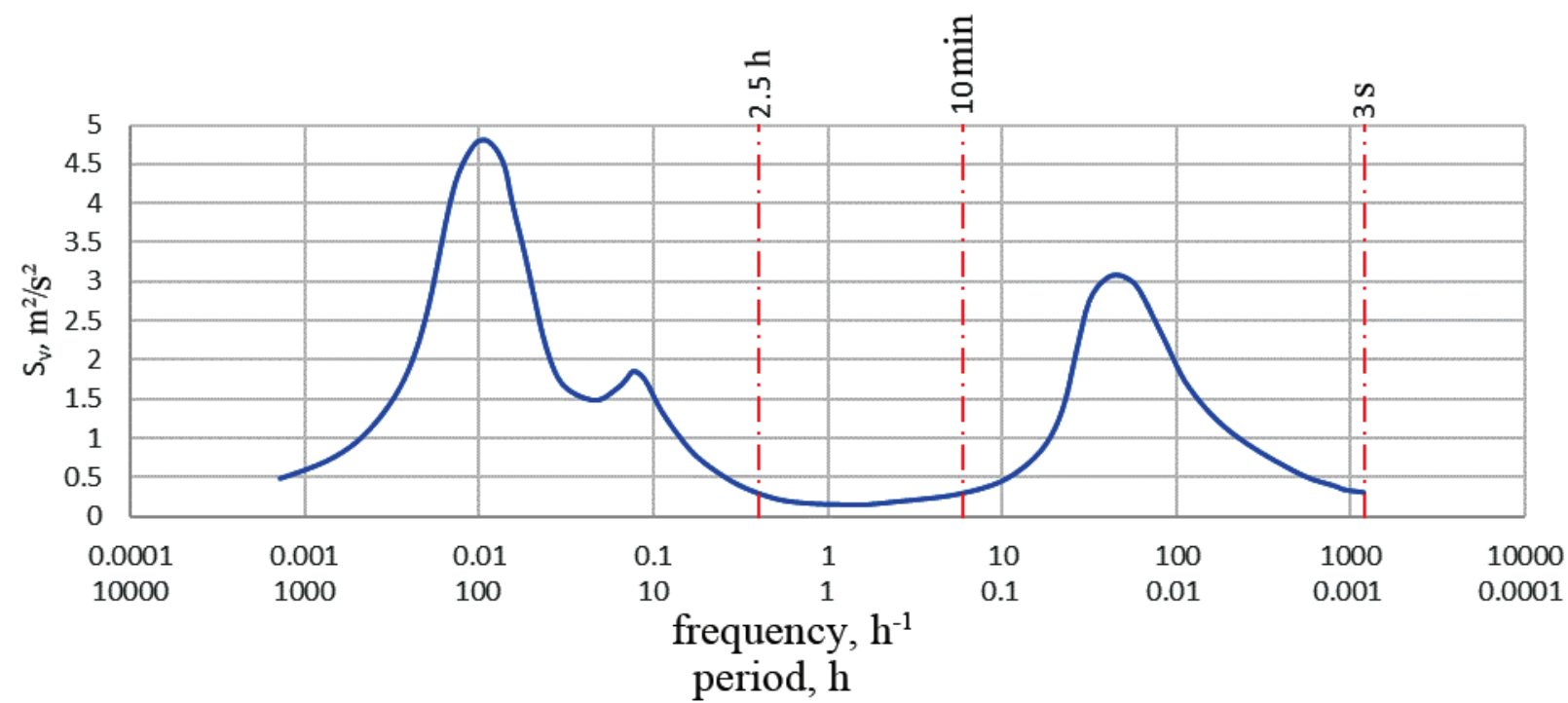

Figure 1. The character of the spectral density of wind speed according to [17]. 


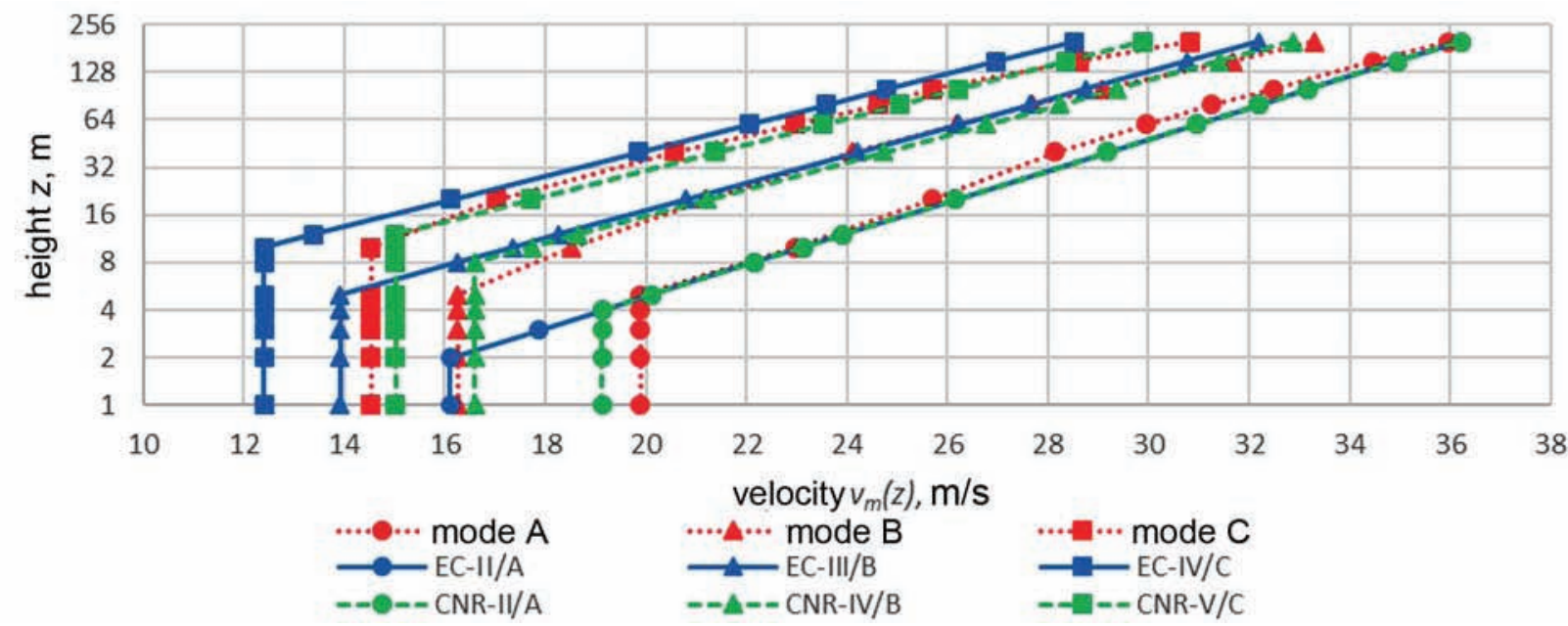

Figure 2. The nature of the profile of the average wind speed $v_{m}(z)$ in different types of terrain according to Russian and foreign design codes.

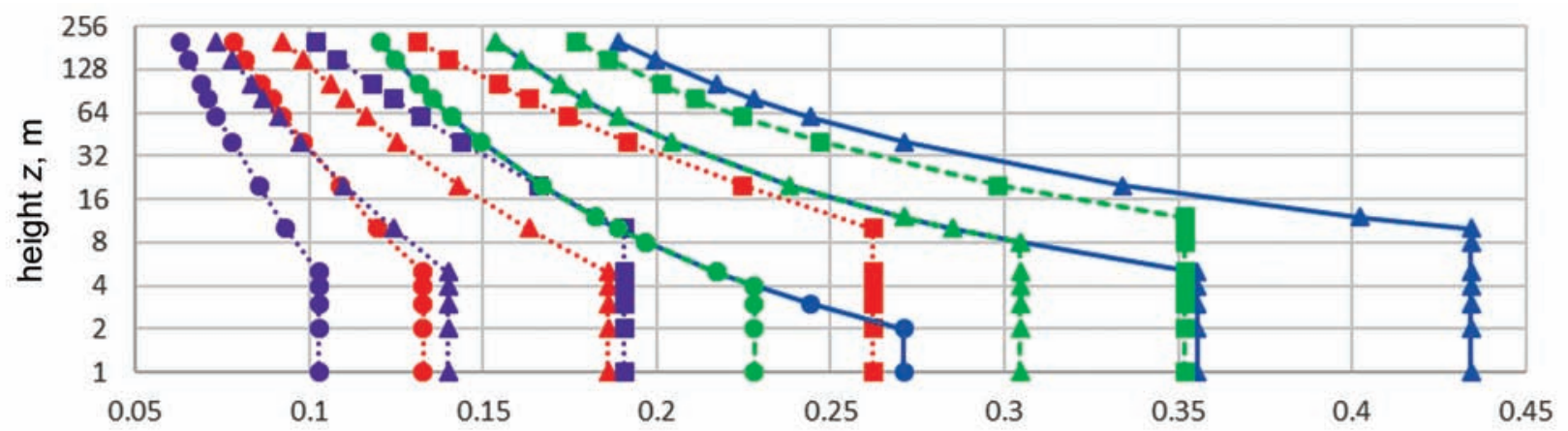

Turbulence intensity $I(z)$, relative unit

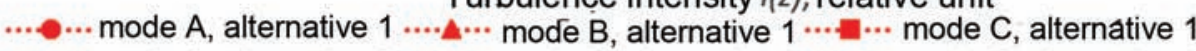

$\cdots \cdot \cdots$ mode $A$, alternative $2 \cdots \cdots$ mode $B$, alternative $2 \cdots \cdots$ mode $B$, alternative 2

$\longrightarrow$ EC-II/A

--O--CNR-II/A --A-- CNR-IV/B

$\longrightarrow \mathrm{EC}-\mathrm{IV} / \mathrm{C}$

$--\mathrm{CNR}-\mathrm{V} / \mathrm{C}$

Figure 3. The nature of the profile of the intensity of wind turbulence $I(z)$ in various types of terrain on the modifications of Russian and foreign design codes.

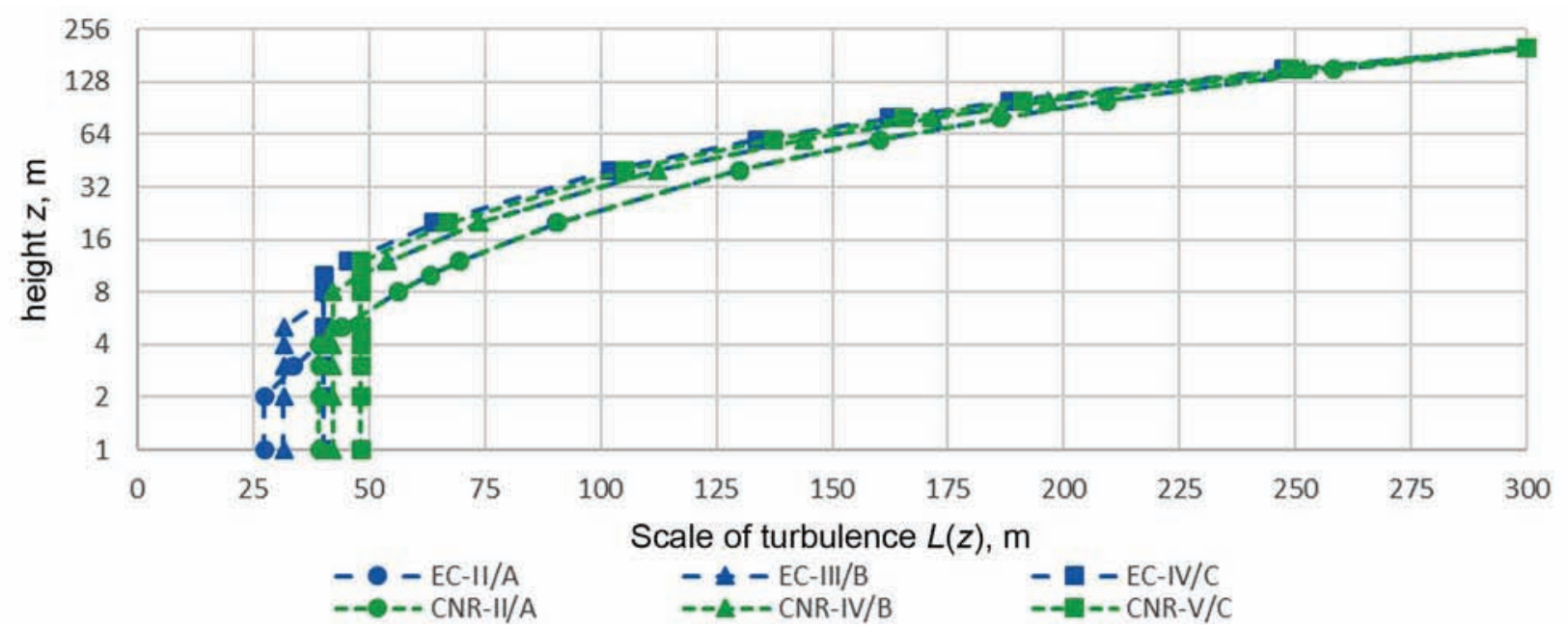

Figure 4. The nature of the profile of the scale of turbulence of the wind $L(z)$ in various types of terrain according to foreign design codes. 